\title{
A SARKVIDÉKTŐL A VILÁGÜRIG: A PSZICHOLÓGIAI TARTALOMELEMZÉS ALKALMAZÁSA IZOLÁLT KISCSOPORTOK VIZSGÁLATÁRA*
}

\author{
EHMANN BEA - BALÁZS LÁSZLÓ
}

MTA TTK Kognitív Idegtudományi és Pszichológiai Intézet

E-mail: ehmann.bea@ttk.mta.hu; balazs.laszlo@ttk.mta.hu

Beérkezett: 2015. június 20. - Elfogadva: 2015. szeptember 14.

\begin{abstract}
Jelen tanulmány alapja a Magyar Pszichológiai Társaság XXIV. Országos Tudományos Nagygyülésén, Egerben elhangzott Mérei Ferenc-emlékelöadás. Konkrét célja, hogy áttekintést adjon az izolált kiscsoportok pszichológiai kutatásáról, ezen belül a földi üranalóg környezetekkel és valóságos ürutazókkal kapcsolatosan végzett pszichológiai tartalomelemzéses vizsgálatokról. Ennek során ismerteti a pszichológiai tartalomelemzés fó típusait - a tematikus, a pszichológiai konstruktum alapú, a narratív pszichológiai és - az esetenként többnyelvü - korpusznyelvészeti tartalomelemzést. Bemutatja ezek szemléletmódját és nyelvtechnológiai feltételeit, valamint a szerzők által végzett hazai és nemzetközi együttmüködésben végzett kutatások néhány eredményét. Tágabb célja, hogy rávilágitson a pszichológiai tartalomelemzés számos területen történö alkalmazhatóságára.
\end{abstract}

Kulcsszavak: izolált kiscsoport, ürpszichológia, pszichológiai tartalomelemzés, narratív pszichológiai tartalomelemzés, korpusznyelvészeti tartalomelemzés, NooJ

\section{BEVEZETÉS}

A szélsőséges környezeti körülmények folytán a Sarkvidék és a Világűr meghódítása számos közös vonásban osztozik. A dicsőséges felfedezői, hősi történetek alkotják és táplálják azt a társadalmi motivációs bázist, amelynek révén szerte a világon ma is ezren és ezren kívánkoznak a Marsra menni, még akkor is, ha a visszatérés esélye jelenleg csekélynek tűnik.

* A tanulmány megjelenését az ESA/PECS 4000108001/13/NL/KML pályázat támogatta. 
A sarkvidéki expedíciók résztvevőinek tollából több mint egy évszázada ismeretesek naplók és emlékiratok. Szerzőik azt sem kendőzték el, hogy a hosszú és viszontagságos összezártságból esetenként súlyos problémák is fakadtak. Az alábbi idézet jól szemlélteti, hogy a mai űrpszichológia által vizsgált problémákkal a hőskor emberei is pontosan tisztában voltak. Második antarktiszi expedíciójának előkészületeiről írva, Byrd admirális a következőképpen elmélkedik:

Már Little America-ban [az első bázison] is volt olyan társam, aki hallgatagságba burkolózott, mert mindenki azzal gyanúsította a másikat, hogy suttyomban áttolja a holmiját az ő számára kijelölt területre; ismertem valakit, aki csak akkor tudott enni, ha olyan helyet talált az étkezőhelyiségben, ahonnan nem láthatta a fletcheristát, ${ }^{1}$ aki minden egyes falatot rendületlenül huszonnyolc alkalommal megrágott, mielőtt lenyelte volna. A sarkvidéki táborban az ilyesféle esetek még a legfegyelmezettebb embert is képesek őrületbe kergetni. Little America-ban töltött első telem során órákig sétálgattam egy emberrel, akit gyilkossági és öngyilkossági gondolatok foglalkoztattak egy olyan társunk általi képzelt üldöztetése miatt, aki egyébként szívbéli jó barátja volt. Mindez azért, mert nincs hova menekülni. Az embert minden oldalról beszorítja saját tökéletlensége és társainak nyomakodó jelenléte. A túlélés során csupán azok képesek magukban bizonyos fokú boldogságot megőrizni, akik mélységesen kiaknázzák szellemi tartalékaikat, a téli álom során saját zsírjukat felemésztő állatokhoz hasonlatosan.

$(\text { BYRD, 1938, 12) })^{2}$

A sarkvidéki expedíciókról szóló könyvtárnyi mennyiségű hiteles írásban csaknem minden olyan mozzanat és körülmény előképe szerepel, ami ma az űrpszichológiai vizsgálódások és bajmegelőzési törekvések tárgyát képezi.

\section{IZOLÁLT ÉS KAPSZULAKÖRNYEZETEK}

Az űrhajózással kapcsolatos pszichológiai tudásbázis az izolált és elzárt, behatárolt környezetekben (Isolated, Confined Environments, ICEs) élő emberek - az ún. ICE-csoportok vizsgálatán alapul. E környezetek két fő típusba sorolhatók. Az egyik típus, amikor az elzártság emberi túlélésre alapvetően alkalmas tágabb környezetben valósul meg. Ide tartoznak az önkéntes vagy kényszerített bentlakásos intézmények (például hajók, börtönök, katonai létesítmények, kórházak, kolostorok), a civilizációtól távol eső ipari telepek (például olajfúró tornyok) és tudományos állomások (például csillagvizsgálók), valamint az űrszimulációs kísérletek színhelyei. A másik típusba az extrém és szokatlan tágabb környezetben, az emberi túlélés optimális határán túl lévő helyek (Extreme and Unusual Environments, EUEs), az ún. kapszulaélőhelyek sorolhatók (például tengeralattjárók, sarkvidéki kutatóállomások, űrhajók). A kapszulába nehéz bejutni és nehéz onnan eltávozni. A kapszula akkor biztosítja a túlélést, ha önellátóan tartalmazza az élethez szüksé-

${ }^{1}$ Horace Fletcher amerikai táplálkozástudós követője.

${ }^{2}$ A szövegrészletet E. B. fordította. 
ges feltételeket, úgymint munka-, lakó- és rekreációs területeket, továbbá az élelmezéshez, az orvosi ellátáshoz és a kommunikációhoz szükséges kellékeket. A kapszula állhat vagy mozoghat, ennélfogva környezete állandó lehet vagy folyamatosan változhat (SUEDFELD és STEEL, 2000).

A földi és az űrbéli kapszulák között a gravitáció megléte, illetve hiánya a legalapvetőbb különbség. Ezért ezeket űranalóg környezeteknek (antarktiszi állomások) vagy üranalóg szimulációknak (például Mars-500, Mars Research Desert Station), összefoglalóan űranalógoknak nevezik. Az űranalógok igen széles skálán helyezkednek el aszerint, hogy a bennük folyó élet milyen mértékben hasonlatos a valódi űrküldetésekhez. Az itt nyert pszichológiai eredményeknek a világűrben való hasznosíthatóságáról számos áttekintő tanulmány született (például SELLS, 1966; KANAS, 1985, 1987; SANDAL, VAERnEs, BERGAN, WARMCKe és URSin, 1996; SANDAL, 2000; HELMREICH, 2000). A kétezres évekre az űrkutatók megegyeztek abban, hogy a földi környezetekben végzett kutatások eredményei nagyrészt érvényesek a világürbeli környezetekben is.

Az űrpszichológiai kutatás jelenleg tehát két szálon folyik: egyrészt a földi űranalógokban, másrészt - ma még kisebb mértékben - a Nemzetközi Ürállomáson.

\section{AZ ÜRHAJÓZÁS KIHÍVÁSAI}

Az ember világűrbeli tartózkodásának története során bizonyos kihívások a kezdetektől máig változatlanul fennmaradtak, és folyamatosan keletkeznek újak. A korai szakaszban az űrutazások rövid időtartamúak voltak; a Nemzetközi Ürállomás legénysége ma már több hónapot is Föld körüli pályán tölt, a tervezett Marsutazás pedig minimum másfél évig fog tartani, sőt néhányan talán végleg le is telepszenek majd a Vörös Bolygón.

KANAS és MANZEY (2008) a stresszorok és a stresszválaszok szemszögéből osztályozza, és négy-négy csoportba sorolja az élettani és pszichológiai problémákat. A jelenleg kivédhetetlen stresszorok egyik csoportját a fizikai veszélyek jelentik. Legfontosabb közöttük a súlytalanság (a mikrogravitáció), ami megterheli és megváltoztatja a szív- és érrendszert, a vesztibuláris és a szenzomotoros rendszert (kezdetben ür-tengeribetegséget okozva); hosszú távon pedig károsítja az izom- és csontrendszert. Maradandó egészségkárosodást is okozhat a megnövekedett ionizáló sugárzás (amelynek hatását jelenleg csak az ürben tartózkodás időtartamának szigorú korlátozásával lehet kivédeni). Megváltozik a sötétség-világosság ciklus (a keringő űrállomáson minden másfél órában felkel a Nap), többek között állandósult alvászavarokat okozva. A másik stresszorcsoportot az űrhajó műszaki adottságai alkotják - egyebek közt a vibráció, a környezeti zaj és a levegő minősége. Az ürhajó levegőjének romlása részint a zárt rendszer, részint a mikrogravitáció következménye, hiszen az esetlegesen elszabaduló szerves anyagok a levegőben lebegnek (szinte cseppenként kell őket begyüjteni). Bármennyire körültekintő is a legénység, fennáll a veszély, hogy az idő múlásával az űrhajók levegője egészségtelenné válik (SUEDFELd és STEEL, 2000). 
A pszichológiai stresszorok is kétfélék. Az egyén számára már önmagában is problémát jelent az izoláció, a bezártság, a folyamatos veszélyhelyzet, a monotónia és a fokozott munkaterhelés. Hozzáadódnak mindehhez a kiscsoportos létből fakadó személyközi stresszforrások: a kulturális különbségek, a genderkérdések, a személyes konfliktusok és a vezetéssel kapcsolatos esetleges problémák. Mindezekre a stresszválaszok széles skálája lehetséges.

A pszichológusok számára tehát egyre tágabb vizsgálódási és beavatkozási terepet jelentenek a hosszú távú ürutazások - mind az űrhajósok kiválasztásakor és felkészítésekor, mind pedig repülés közben és a földi életbe történő visszailleszkedésük során.

\section{AZ ÜRPSZICHOLÓGIA TÉMAKÖREI}

Az űrpszichológia témakörei négy fő csoportba sorolhatók: a legénység teljesítményét és személyközi kapcsolatait elemző kutatások, az egyéni tünetek és szindrómák vizsgálata, és a pozitív pszichológiai törekvések.

Az űrkutatással kapcsolatos stresszhatások (súlytalanság, alvászavarok, fokozott munkaterhelés) a kognitív teljesítőképesség hanyatlásához vezetnek. A földi irányítás figyelemmel kíséri és elemzi az emberi hibákat, de az így gyűjtött adatok összehasonlítási alap hiányában nem adnak támpontot a változás mértékére. A kognitív idegtudomány területén végzett tudományos vizsgálatok a kognitív feladatokban mutatott reakcióidőt és hibázásokat elemzik, ritkábban az agyi elektromos aktivitás mérésével együtt. A témáról és az ezen a területen folyó magyar kutatásról bővebben lásd: BALÁzs, BARKASZI, CZIGLER és TAKÁCS, 2015.

A csoportdinamikai kutatások a legénység létszámának hatásait és a vezetői szerepeket vizsgálják. Eszerint a kétfős személyzet a legrosszabb változat; ennél egy fokkal jobb a háromszemélyes küldetés. A jelenlegi álláspont szerint a minél több főből álló, páratlan létszámú legénység az optimális; a vezetés szempontjából pedig az, ha a vezető jól ötvözi a feladatorientált és a támogató szerepkört (KANAS és MANZEY, 2008). Fontos kutatási terület a csoporton belüli és a külvilággal - esetenként a földi irányítószemélyzettel - folytatott kommunikáció jellegzetességeinek vizsgálata is. (Kelly és KANAS, 1992; KANAS, SALNITSKiY, GUSHIN és mtsai, 2001; GuSHIN, 2003).

Jelentős ágazat az egyéni tünetek és szindrómák vizsgálata is.

A sarkkutatásban a leggyakrabban kutatott jelenség az áttelelési szindróma (winter-over syndrome). Első leírása STRANGE és YOUNGMAN (1971) nevéhez füződik. Lényege, hogy az emberek rosszul alszanak, gondolkodásuk lelassul, negatív érzelmek uralják el őket, és minden felnagyított apróságon sokat veszekszenek. Minthogy ezek a tünetek az expedíciók félidejétől kezdve erősödnek fel, a küldetés vége felé pedig csökkennek, a tünetegyüttest harmadik negyedbeli jelenségnek, avagy Q3 szindrómának is nevezik (BECHTEL és BERNING, 1991). Fontos szerepet kap a szubszindromális szezonális affektív zavar (SAD) kutatása is (Palinkas és Suedfeld, 2008). 
Az űrkutatásban a helyzet még összetettebb. A fentebb említett pszichológiai stresszorokra adott negatív stresszválaszok között említhetjük, hogy az űrhajók legénysége beszüntetheti a földi irányítással való kommunikációt; romolhat a munkateljesítmény, személyközi ellenségeskedés vagy visszahúzódás alakulhat ki. Ez utóbbi súlyos formáját ROHRER (1961) nyomán „long-eye szindrómának” is nevezik, ami abból áll, hogy a legénység kiközösített tagja akár kataton állapotba is kerülhet - túlnéz a falon, kibámul a semmibe. A küldetést és az életet veszélyeztető gondatlanság vagy feledékenység, fáradtság, aszténia és ideges feszültség jelentkezhet (KANAS, SALNITSKIY, WEISS és mtsai, 2001). A pszichológiai stresszforrások és stresszválaszok listázása és elemzése napjainkban már ott tart, hogy a bolygóközi utazás kapcsán a „Már nem látszik a Föld” (Earth-out-of-View) tünetegyüttest is kezdik emlegetni (KANAS és MANZEY, 2008).

A korai, rövid időtartamú űrküldetések során a pszichológiai problémák még nem voltak számottevőek. Ha mégis felmerült valamely probléma, akkor az orvosi és műszaki gondolkodás jegyében azonnal kidolgozták a megfelelő ellenintézkedést (psychological countermeasure), s lényegében ma is ez az uralkodó hozzáállás.

\section{VÁLTOZÓ SZEMLÉLETMÓD}

Már a Salyut (1971-1986), a Skylab (1973-1979) és a Mir (1986-2001) űrállomások korában is megjelentek, ma pedig a Nemzetközi UUrállomás (International Space Station, ISS, 2000-től) és a tervezett Mars-utazás miatt még fokozottabban előtérbe kerülnek a hosszú távú űrutazás pszichológiai szempontjai. Az ürpszichológia prioritásai ezért jelenleg változóban vannak. Peter SUEDFELd (2005) négy fázist különít el e téren.

Az első fázist a szerző „right stuff” mentalitásnak nevezi. A fogalom ma is széleskörűen használatos a NASA-szlengben; szójáték a 'staff mint személyzet és a 'stuff' mint 'cucc', 'izé' jelentésekkel (WOLFE, 1979). E szemléletmód arra irányul, hogy a legkiválóbb, legrátermettebb embereket kell kiválasztani, s belőlük összeillő tulajdonságokkal rendelkező legénységeket kell összeállítani (SANTY, 1994). Ebben az időszakban a pszichológusok szerepe jórészt a legénységek kiválasztásában végzett tevékenységre korlátozódott. A kiválasztás a mai napig három lépésben történik. A kiszürési (select-out) szakaszban személyiségtesztek segítségével utasítják el az alkalmatlan jelentkezőket. A beszürési (select-in) szakaszban számos módszerrel vizsgálják a jelölteket. Ennek végére összeáll tehát egy minden szempontból kitűnő jelöltcsoport; a harmadik fázisban (right stuff) belőlük állítják össze a tényleges legénységeket. Ennek során már figyelembe veszik, hogy a különböző típusú küldetések más-más személyiségszerkezetet igényelnek. A legfontosabb a mentális és érzelmi stabilitás és a stresszteli körülmények közötti jó teljesítőképesség; a csoportos együttélési képességek a hosszú távú küldetések során a harmadik helyen szerepelnek, ám a rövid távú küldetésekben ezek a hetedik helyre szorulnak vissza (GALARZA és Holland, 1999, idézi és kommentálja KANAS és MANZEY, 2008). Suedfeld szerint ez a gyakorlat az invulnerabilitási hipotézist implikálja, vagyis hogy a right stuff egyúttal sérthetetlen, sebezhetetlen a stresszel szemben. 
A szemléletmód második fázisa során - a múlt század hetvenes éveiben - a kutatók ráébredtek, hogy az optimálisan összeválogatott legénység sebezhetetlensége csupán mítosz, és ezért megindult a reziliencia (azaz a negatív hatásokból való teljes kilábalás) felé irányuló fókuszváltás. A harmadik fázisban a pathogenetikus szemléletmód mellett már teret nyert a szalutogenetikus, illetve a pozitív pszichológiai gondolkodás, ahol a küldetések kedvező utóhatásai is szerepet kapnak. Negyedik fázisként a szerző egy „integrált, komplex Gestaltot” vázol fel, amelyben a kiválasztásra és a küldetések sikerességére való törekvések mellett oda kell figyelni az űrkarrierjüket befejező férfiak és nők életének alakulására is.

\section{UTÁNKÖVETÉSES VIZSGÁLATOK ÉS POZITÍV PSZICHOLÓGIA}

Az antarktiszi áttelelők egyik legkorábbi utánkövetéses vizsgálata során az amerikai Deep Freeze Operation program katonai adatbázisa alapján több mint 300 áttelelő és 2400 kontrollszemély orvosi adatait követték nyomon egy 15 éves időtartam során, 1965-től 1979-ig. A kutatás legfontosabb megállapítása az volt, hogy az antarktiszi áttelelésnek nincs hosszú távú egészségkárosító hatása (PALINKAS, 1986). Az, hogy a legénység a szélsőségesen megterhelő körülmények között is egészséges maradhat, elsősorban a küldetések pozitív velejáróinak köszönhető. A pozitív élményeket, a transzcendencia és a személyes növekedés vonatkozásait küldetések közben is vizsgálták (Mocellin és SuedFeld, 1991; LeON, SANDAL, Fink és CIOFANI, 2011). A személyes növekedés jelenségét későbbi vizsgálatok is megerősítették; a 2000-es évek elejétől a téma irodalmában egyre markánsabban felbukkan a szalutogenezis (ANTONOVSKY, 1979, 1987) gondolata, illetve nyomán megjelenik a pozitíu kapszula pszichológia fogalma (SuEDFELD és STEEL, 2000). A küldetések legfontosabb szalutogenetikus utóhatásai a következők: javul a személyes teljesítmény érzése, a kötődési, együttműködési és intimitási készség; megnövekszik az önbecsülés, a határozottság, a szívósság, a reziliencia és a megküzdési képesség. A résztvevők humánus, autonóm és spirituális személyiséggé válnak (PALINKAS és SUEDFELD, 2008).

\section{Kihivuás utáni növekedés vizsgálata}

Sarkvidéki környezetben számos egyéb mérőeszköz mellett a Poszttraumás növekedési kérdö́vet (PTGI) (TEDESCHI és CALHOUn, 1996) használták (LEON, SANDAL, Fink és CiOfani, 2011).

Az ürrepülés pozitív hatásainak vizsgálatára a PTGI nyomán IHLE, RITSHER és KANAS, 2006) kialakították a 8 skálából ${ }^{3}$ álló, 36 tételes, Az ürbéli tartózkodás pozitív hatásai nevủ kérdőívet (Positive Effects of Being in Space, PEBS). Összesen 39,

\footnotetext{
${ }^{3}$ A Föld észlelése (Perceptions of Earth), A Világür észlelése (Perceptions of Space), Új lehetőségek (New Possibilities), Az élet tisztelete (Appreciation of Life), Személyes erö (Personal Strength), Változások a mindennapi életben (Changes in Everyday Life), Másokhoz való viszony (Relating to Others) és Spirituális változás (Spiritual Change).
} 
nagyrészt amerikai űrhajós résztvevőt kértek fel ennek kitöltésére, akik 6 pontos Likert-skálán értékelték az észlelt változást. A vizsgálat eredményei szerint az űrutazás minden résztvevő számára jelentésteli, pozitív élmény volt. A legkisebb növekedést a spiritualitás növekedése terén találták, a legnagyobbat pedig a Föld észlelése skálán - azaz, az űrhajósok ráébredtek a Föld szépségére és sérülékenységére.

A vizsgálat egy konkrét, a jövőre vonatkozó gyakorlati gondolatot is felvetett. A jelentős pozitív változást mutatók ugyanis a Föld észlelése mellett a Világür észlelése skálán adtak magasabb pontszámokat. Ebből a szerzők azt a következtetést vonták le, hogy - a fentebb említett Earth-out-of-view szindróma fényében - olyan embereket kell majd a Marsra küldeni, akiket a Világür végtelensége sokkal jobban elbűvöl, mint Kék Bolygónk szépsége.

A hosszú időtartamú űrutazás pozitív hatásainak vizsgálatát orosz mintán is elvégezték. A moszkvai Institute for Biomedical Problems (IBMP, ahol a későbbiekben említendő Mars-500 űrszimulációs vizsgálat is zajlott) 20 veterán kozmonautát kért fel egy kérdőívbattéria kitöltésére, melyet kanadai együttműködésben elemeztek (SUEDFELD, BRCiC, JOHNSON és GUSHIN, 2012). A battériában szerepelt a fentebb említett PEBS, valamint a PTGI egy, a szerzők által összeállított másik változata, a Tapasztalat utáni változás kérdőív (Post-Experience Change Inventory, PECI). A PEBS-szel nyert adatokat összehasonlították az Ihle és munkatársai által nyert eredményekkel. A változás erősségének skálasorrendje - noha az orosz mintán több esetben szignifikánsan nagyobb mértékű volt - a két vizsgálatban nagyjából hasonló mintázatot mutatott.

A szalutogenetikus szemlélet és a pozitív pszichológiai gondolkodásmód tehát évtizedek óta folyamatosan fejlődik és szervesen integrálódik az űrpszichológia többi témaköréhez. Kutatásai hozzájárulnak ahhoz, hogy a megfelelő embereket válasszák ki, a küldetések sikerüljenek, és a legénységek fizikai és mentális állapota a lehető legkevesebb kárt szenvedje, beleértve a polgári életbe történő visszailleszkedést is.

Tanulmányunk következő részében azt mutatjuk be, miképpen alkalmazhatók a pszichológiai tartalomelemzés különféle típusai izolált kiscsoportok vizsgálatára.

\section{A PSZICHOLÓGIAI TARTALOMELEMZÉS SZEMLÉLETMÓDJA ÉS TÍPUSAI}

A tartalomelemzés módszertanáról szóló átfogó munkák kimerítően tárgyalják a témakör egymásból kibomló és esetenként egymással vitatkozó definícióit és alkalmazásait (BERELSON, 1952/1971; HOLSTI, 1969; KRIPPENDORFF, 1988, 2004; NEUENDORF, 2002). Ezek azonban számunkra kevés fogódzót nyújtanak. Részint azért, mert a tartalomelemzés szemléletmódja folyamatosan, napjainkban pedig különösen gyors ütemben változik. Második könyvében KRIPPENDORFF (2004) azt írja, hogy a tartalomelemzésben négy konceptuális forradalom zajlott le, nevezetesen az üzenetekről, a csatornákról, a kommunikációról és a rendszerekről való gondolkodás kapcsán, és jelenleg az ötödik, a komputációs forradalom kellős köze- 
pén tartunk. Ez a jelenleg már több mint tíz éve volt. Azóta kialakult az adatbányászat (data mining), a szövegbányászat (text mining), a rendkívül terjedelmes szövegkorpuszok elemzésének módszertana (big data analysis) és az érzelmek és vélekedések nagyrészt online elemzésével kapcsolatos eljárás (sentiment analysis). Kialakult a korpusznyelvészet (corpus linguistics), megjelentek a természetes nyelvfeldolgozási (Natural Language Processing, NLP) technikák.

Mindezek eredményeként talán nem túlzás úgy fogalmaznunk, hogy napjainkban a számítógépes tartalomelemzés a felnagyított kogníció (augmented cognition; lásd erről BARANYI és CSAPÓ, 2012) egyik formája. Ez a fogalom arra utal, hogy a fejlett technológia olyan világokba is bepillantást enged az ember számára, amire korábban nem volt példa (például az $f \mathrm{MRI}$ ). A pszichológiai tartalomelemzés esetében ez azt jelenti, hogy a lyukkártyás számítógépek megjelenése óta egészen a mai korpusznyelvészeti platformokig (lásd alább) egyre növekvő mértékben láthatunk „a szöveg mélyére”, ahol szabad szemmel, pusztán szövegolvasás révén nem érzékelhető mintázatokat vehetünk észre (lásd erről EHMANN, 2002).

A másik ok, amiért nem tudunk hiteles, egyértelmű meghatározást közölni, az az, hogy a tartalomelemzés klasszikus szerzői elsősorban az ún. tematikus elemzéssel foglalkoznak, és csak érintőlegesen tárgyalják a pszichológiai tartalomelemzés kérdéseit, nem ragadják meg annak lényegét.

A pszichológiai tartalomelemzés OSGOOD (és WALKER) (1959) nyomán abból a feltételezésből indul ki, hogy a beszélők (az üzenetek alkotói) szándékosan vagy akaratlanul számos olyan jelet kódolnak bele az általuk alkotott szövegekbe, amelyek a megfelelő módszerekkel rendelkező üzenetelemzők által dekódolhatóak. Úgy is fogalmazhatunk, hogy a szövegben lévő nyelvi markerek azonosítása és számlálása révén a beszélők pszichológiai állapotaival és folyamataival következtetéseket vonhatunk le.

WEINTRAUB (1989) szerint a névmások és funkciószavak (például tagadószók, módosítószók, magyarázószók, nyomatékosító szók stb.) használatából messzemenő következtethetések vonhatók le; egyebek közt a preferált elhárító mechanizmusok és bizonyos klinikai állapotok is kimutathatóak.

Napjainkban Pennebaker: The Secret Life of Pronouns - What our Words Say about Us [A névmások titkos élete - Mit mondanak rólunk a szavaink] (2011) címú, a szerző csaknem egész életművét átfogó könyve tekinthető a pszichológiai tartalomelemzés egyik legfontosabb kézikönyvének. Vezérfonala, hogy ne a tartalomra figyeljünk, hanem a stílusra („,Ignoring the content, celebrating the style”); azaz, pszichológiai állapotaink és folyamataink mindenképpen bekódolódnak szövegeinkbe, bármiről beszélünk is.

Pennebaker munkacsoportja fejlesztette ki a Linquistic Inquiry and Word Count (LIWC) nevü, angol nyelvterületen hosszú évek óta a világon a leggyakrabban használt pszichológiai tartalomelemző szoftvert. ${ }^{4}$ A LIWC és a hasonló szógyakoriság alapú tartalomelemző szoftverek egyik hátránya, hogy csak angol nyelvű szövegek elemzésére alkalmasak. Történnek törekvések e szoftverek szólistáinak más nyelvekre fordítására, de ezek alkalmazása meg sem közelíti az eredeti LIWC elterjedtségét.

4 http://www.liwc.net/ 
Az angol nyelvű szoftverek dominanciáját megtörni látszik a nemzeti nyelvű korpusznyelvészeti fejlesztőprogramok színrelépése. Magunk is ezt használjuk, amint erről az alábbiakban szót ejtünk.

A pszichológiai tartalomelemzés logikai szerkezete alapvetően négy fő szegmensből áll: az adatbázis meghatározásából és összeállításából, a kérdésfeltevésből, a tartalomelemzés elvégzéséből, és végül az eredmények statisztikai feldolgozásából és pszichológiai értelmezéséből.

Az adatbázist maga az elemzendő szövegkorpusz és az ehhez tartozó független változók és kovariánsok alkotják. A kérdésfeltevés határozza meg, milyen céllal, milyen adatokat fogunk számlálni a szövegekben. A tartalomelemzés módszere többféle lehet. A választott módszer határozza meg, hogy kézzel kódolunk-e vagy elektronikusan összeállított szövegbázison tartalomelemző szoftvereket futtatunke. Az eredmények statisztikai feldolgozása a választott tartalomelemzési módszer által megengedett mértékben lehetséges. A kis mintán végzett, feltáró jellegű tartalomelemzés (pilot study) célja a szövegbázis feltérképezése; ennek során arra vagyunk kíváncsiak, hogy milyen - szabad szemmel kevéssé látható - mintázatok tárulnak fel a szövegben, amelyek későbbi vizsgálódásra érdemesek. A nagyobb mintán, szoftverek segítségével végzett elemzések már egyének és csoportok összehasonlítására, valamint longitudinális folyamatelemzésére is alkalmasak. Ez utóbbi esetben a statisztikai eredmények validitása és reliabilitása elérheti a pszichometriai módszerekkel végzett kutatások szintjét.

Az alábbiakban néhány példán bemutatjuk a pszichológiai tartalomelemzés típusait. A példákat eseti beszámolókon, űranalóg környezetekben és a Nemzetközi Úrállomáson végzett vizsgálatok adják. Saját vizsgálatainkról is szót ejtünk. A példákat a tartalomelemzés típusa, nem pedig kézi végrehajtás vagy az alkalmazott szoftver szerint csoportosítottuk - elvben ugyanis minden típus esetében lehetőség van szoftverhasználatra.

\section{TEMATIKUS TARTALOMELEMZÉS}

A tematikus tartalomelemzés a több kódoló által, kézzel végzett, kvalitatív tartalomelemzés hagyományos formája. Alábbi példánk azért tekinthető fontosnak, mert csaknem ugyanazt a kategóriarendszert alkalmazták sarkvidéki állomásokon és a Nemzetközi UUrállomáson keletkezett szövegek elemzésére. Mindkettőt a NASA megbízásából végezték. A tartalomelemzési kérdés azon a feltételezésen alapult, hogy az emberek a számukra fontos dolgokról többet beszélnek, s így a kutatók arra voltak kíváncsiak, milyen témakörök fontosak a két csoport számára.

A sarkvidéki elemzést Francia napló vizsgálat néven jegyzik. STUSTER és munkatársai kilenc (angol nyelvre lefordított) naplót elemeztek, melyeket az Antarktiszon és a Dél-Indiai Óceán kis szigetein lévő kutatóállomásokon dolgozó orvosok és kutatócsoport vezetők írtak. A bejegyzésekről bekezdésenként döntötték el, hogy milyen kategóriába tartoznak. Összesen 1810 bekezdést vizsgáltak; ezeket 22 témába sorolták be. Ha valamely bekezdés egyszerre több témát is érintett, akkor azt ún. másodlagos kategóriaként több témába is besorolták. Így például a Csoport 
Interakció témakör 330 bekezdésben jelent meg elsődleges, és 275 bekezdésben másodlagos tartalomként; összesen tehát 605 alkalommal szerepelt, vagyis - leggyakoribb előfordulásként - az összes bejegyzés egyharmadát érintette. A földi izolált kiscsoportok további kiemelkedő témáit a Külső kommunikáció, a Munkaterhelés, a Szabadidós tevékenység, az Orvosi támogatás, az Alkalmazkodás és a Vezetés alkotta. A témakör szerint azonosított bekezdésekről megállapították továbbá, hogy a bejegyzés negatív, semleges vagy pozitív tónusú volt-e. E kódolás eredményeként egy Nettó Pozitivitás/Negativitás (NPN) elnevezésű mérőszámot alakítottak ki. Ezután kiszámolták, hogy a talált értékek milyen megoszlást mutatnak összességében és a küldetések egyes negyedeiben. A szerzők számos hasznos eredményt kaptak, ám a legérdekesebb az volt, hogy a naplóírók az amúgy harmonikusnak tekintett csoportok apró-cseprő konfliktusaival foglalkoztak a legtöbbet. A vizsgálat - sok hasonló kutatáshoz hasonlóan - kimutatta, hogy a küldetés időtartamától és helyétől függetlenül a csoportok érzelmi állapota a harmadik negyedben volt a legalacsonyabb. A szerzők elvárásaival ellentétben, a rövidebb időtartamú és a szigeteken (tehát nem az Antarktiszon) folyó küldetések nagyobb negativitást mutattak (STUSTER, Bachelard és Suedfeld, 1999, 2000).

A Francia napló vizsgálatot tíz évvel később a Nemzetközi Űrállomás résztvevőivel is megismételték. Ezúttal 10 olyan űrhajós naplóit elemezték, akik átlagosan 187,7 napot töltöttek az űrállomás fedélzetén. A vizsgálat a korábbinál finomabb témafelbontással történt. A bejegyzések mintegy felét harmadik kategóriába is besorolták; két új kategóriaként bevezették a Logisztika/Tárolás és az Eljárások/Rituálék nevủ témákat, illetve a főkategóriákat további alcsoportokra bontották.

$\mathrm{Az}$ alkategória elemzések több fontos felismeréshez vezettek. Az űrhajósok egyik legfóbb problémája az volt, hogy az egyes feladatok elvégzésére túlságosan kevés időt kaptak, folyamatosan késésben voltak, s így szabadidejük egy részében is dolgoztak. A kutatók mélyebb belátást nyertek az alantas, unalmas és frusztráló munkákkal (lényegében a „házimunkával”) kapcsolatos vélekedésekbe. Az is kitűnt, hogy az apró kellemetlenségek felnagyítása az űrhajón a földi kapszuláknál is fokozottabb mértékben jelen van. Végül, de nem utolsósorban az ürhajósok azt is leírták, milyen sokat segített nekik a naplóírás a fedélzeti élethez és munkához való alkalmazkodásban. Mindezek alapján a szerzők az űrhajósok teljesítményének növelésére és pszichológiai jóllétük javítására irányuló ajánlásokat fogalmaztak meg a NASA számára (STUSTER, 2010).

\section{PSZICHOLÓGIAI KONSTRUKTUM ALAPÚ TARTALOMELEMZÉS}

Pszichológiai konstruktum vezérelte tartalomelemzésről akkor beszélünk, ha a kutatói kérdésfeltevés nem az összes lehetségesen előforduló témára vonatkozik, hanem valamely előre meghatározott konstruktumot illetően célzott összehasonlításokat kíván tenni akár két vagy több személy vagy csoport között, illetve egyazon személy vagy csoport különböző időpontokban felvett szövegmintái között. 


\section{Értékhierarchiák változása ürutazás hatására}

Peter SUEDFELD (2006) 10 amerikai űrhajós (7 férfi és 3 nő) és 2 magas rangú NASA alkalmazott (2 férfi) emlékirataiban vizsgálta a Schwarz-féle (SCHWARTZ, 1992) Teljesítményre, a Hedonizmusra, a Jóakaratra és a Transzcendenciára vonatkozó említéseket űrutazás előtt és után. A betanított kódolók által végzett kézi tartalomelemzés módszere az volt, hogy minden oldalon megszámlálták, hány említés esik egy-egy értékre, majd a kapott számot elosztották a vizsgált oldalak számával. Azt találták, hogy a NASA alkalmazottak (mint kontrollok) értékei nem mutattak lényeges változást; a férfi űrhajósok Teljesítmény említései nem változtak, a nők Teljesítmény említéseinek száma azonban az űrrepülés után csaknem az eredeti érték egytizedére esett vissza. Az űrutazást követően a férfiak Transzcendencia említéseinek száma megtízszereződött, a nőké megduplázódott.

Egy másik tanulmányában a szerző négy híres amerikai űrhajós - John Glenn, Gordon Cooper, Buzz Aldrin és Michael Collins ${ }^{5}$ - publikált emlékiratait vetette alá tematikus tartalomelemzésnek. Ezúttal is a Schwartz-féle értékkategóriák említéseit számlálta. Mind a négy memoárt három részre osztotta fel, aszerint, hogy az azokban elmondottak az űrkarrier előtti, alatti és utáni életszakaszra vonatkoztak-e. Egyebek közt azt találta, hogy Aldrin a többiekhez képest kiugróan magas arányban írt a Teljesítmény értékkategóriáról, és vajmi kevéssé említett a Hedonizmus kategóriába sorolható tartalmakat. Ez azért figyelemreméltó - írja a szerző mert Aldrinról tudjuk, hogy űrhajós pályafutása végeztével depressziós és alkoholfüggő lett, és elképzelhető, hogy e problémáit az okozta, hogy egész életét a teljesítményre való törekvés vezérelte, és NASA-karrierje végeztével élete e fó értékét elvesztette (SUEDFELD és WEISZBECK, 2004).

Az ilyen és ehhez hasonló pilot studyk jelentősége abban áll, hogy a kapott eredmények alapján a későbbiekben átfogóbb vizsgálatok alapjául szolgálnak - ez utóbbi esetben például felmerül, hogy a magas Teljesítmény és az alacsony Hedonizmus pontszám mennyiben képes előre jelezni a sikeres pályafutást abbahagyni kénytelen emberek egészségromlásának kockázatát.

Tartalomelemzéssel sokféle más pszichológiai konstruktum is elemezhető - űrhajósok körében egyebek közt megküzdéssel (SUEDFELD, BRCIC és LEGKAIA, 2009) és a Kelly-féle személyes konstrukciókkal kapcsolatos vizsgálatokat is végeztek (Gushin, Efimov, Smirnova, Vinokhodova és Kanas, 1998).

\footnotetext{
${ }^{5}$ John Glenn volt az első amerikai űrhajós, aki körülrepülte a Földet, 1962-ben; majd 1998-ban, 77 évesen, újra űrutazáson vett részt, s így egyúttal ő volt a legidősebb űrben járt ember is. Gordon Cooper a Mercury Program keretében, 1963-ban az első ember volt, aki 36 órás repülése közben űrhajóban aludt. Buzz Aldrin Az Apollo 11 program keretében, Neil Armstrong után, 1969-ben második emberként lépett a Holdra. Michael Collins ugyanebben a küldetésben a Hold körül keringő űrhajóban maradt.
} 


\section{NARRATÍV PSZICHOLÓGIAI TARTALOMELEMZÉS}

A narratív pszichológiai tartalomelemzés hátterét egy Magyarországon kifejlesztett eredeti elméleti modell, a László János iskolateremtő munkásságának eredményeként létrejött tudományos narratív pszichológia alkotja. Az elmélet fókuszában az identitáskutatás áll. Kiinduló elve, hogy az egyének és a csoportok saját identitásukat történetek révén alkotják meg; e történeteket különböző kompozíciós elvek révén hozzák létre, s e kompozíciós elvek tükrözik a szövegek létrehozóinak pszichológiai állapotait és folyamatait. (lásd LÁSzLó, 2005, 2008).

A narratív pszichológiai tartalomelemzés ennek az elméletnek a módszere: arra szolgál, hogy az egyének és csoportok pszichológiai és identitásállapotai és -folyamatai diagnosztizálhatók és előre jelezhetők legyenek (LÁSZLÓ, EHMANN, PÉLEY és PÓlYA, 2002). Szoftvere az MTA TTK Kognitív Idegtudományi és Pszichológiai Intézetében és a Pécsi Tudományegyetemen magyar nyelvű szövegek vizsgálatára kifejlesztett, moduláris rendszerű, narratív kategoriális elemzésre alkalmas NARRCAT. A szoftver kifejlesztését több előfeltétel és sokéves intézményi együttműködés tette lehetővé. ${ }^{6}$ Az egyik előfeltétel a korpusznyelvészet kialakulása, ezen belül a Magyar Nemzeti Szövegtár létrehozása az MTA Nyelvtudományi Intézetében (lásd erről http://mnsz.nytud.h/, valamint ORAVECZ, VÁRADI és SASS, 2014). A másik előfeltétel a Max Silberztein által kifejlesztett NooJ korpusznyelvészeti fejlesztő környezet (http://www.nooj-association.org/), ezen belül a magyar erőforrások (http://corpus.nytud.hu/nooj) létezése. Összefoglalóan lásd erről: LÁszLó, CSERTŐ, FÜlÖP, FERENCZHALMI, HARGITAI, LENDVAI és mtsai, 2013; valamint magyarul Ehmann, Csertő, FülöP, KőVÁGÓ, PÓlya és LÁSZló, 2014).

A narratív pszichológiai tartalomelemzés módszerét az MTA TTK KPI és a Pécsi Tudományegyetem munkatársai számos empirikus területen alkalmazták; az utóbbi időben megindult a narratív szociálpszichológia elmélet fejlődése is (LÁszLÓ, 2012, 2013; LÁSzló és Ehmann, 2014; FülöP, Csertő, Ilg, SZABÓ, Slugoski és LÁSZló, 2014; Vincze, Ilg és Pólya, 2014).

Izolált kiscsoportok pszichodinamikájával kapcsolatos első vizsgálatunkat a tudományos narratív pszichológia keretében, a NARRCAT Érzelem, valamint Szelf-és Mi Referencia moduljainak segítségével végeztük. A vizsgálat helyszíne az Egyesült Államokban, Utah államban lévő, a Mars Society által üzemeltetett Mars Desert Research Station (MDRS) volt, ahol a HungaroMars projekt keretében egy hattagú magyar legénység is eltöltött két hetet. A küldetés tagjai által magyar nyelven írt naplókat elemeztük.

A Pozitív és Negatív Érzelem említésekből az Emocionalitás mutatót, a Szelf-és MiReferencia említésekből pedig a Csoportkohézió mutatót számoltuk ki. Eredményeink szerint még e rövid időtartamú küldetés során is megjelent a fentebb említett Q3 jelenség, a harmadik negyedbeli érzelmi diszfória. A narratív pszichológiai elem-

6 Együttműködő intézmények: MTA TTK Kognitív Idegtudományi és Pszichológiai Intézete; Pécsi Tudományegyetem; MTA Nyelvtudományi Intézete; Szegedi Tudományegyetem; MorphoLogic Kft., valamint a Szegedi Tudományegyetemen 2003 óta évente tartott Magyar Számítógépes Nyelvészeti konferenciák, mely utóbbiak konferenciaköteteiben megjelent tanulmányok online is olvashatók (http://rgai.inf.u-szeged.hu/mszny2015). 
zés során a két összetett mutató együttes elemzéséből azt a következtetést vontuk le, hogy a negatív érzelmi állapot és az alacsony csoportkohézió csoporton belüli konfliktust jelez, a magas csoportkohéziós pontszámmal együtt járó negatív érzelmi állapot pedig a csoport fenyegettség érzésének a jele (EHMANN, BALÁzs, FÜLÖP, Hargitai, Kabai, PÉley és mtsai, 2011). Az ilyen és ehhez hasonló felismerések a későbbiekben nagyobb mintán történő elemzéseket is lehetővé tesznek.

A NARRCAT segítségével folytatott narratív pszichológiai tartalomelemzéseket tehát magyar nyelvű szövegeken végeztük. A korpusznyelvészeti megközelítés azonban több nyelvű szövegeken végzett vizsgálatokat is lehetővé tesz.

\section{KORPUSZNYELVÉSZETI TARTALOMELEMZÉS}

A korpusznyelvészeti pszichológiai tartalomelemzés a nyelvészettel szoros kapcsolatban álló interdiszciplináris terület.

A szövegkorpusz (szövegtest), számítógép segítségével kezelt, célzottan összeválogatott szövegek terjedelmes halmaza. Többféle meghatározása és típusa létezik (lásd erről SzIRMAI, 2005). A nyelvészeti korpusz olyan elektronikusan létező szövegek gyűjteménye, amelynek szavait és kifejezéseit a nyelvészek különféle egyezményes jelekkel, ún. annotációkkal látják el. A sztenderd annotációk két leggyakoribb formája a szófaji címkézés (Part of Speech /POS/ tagging) és a szintaktikai kapcsolatok jelölése (parsing). Az annotálást korszerű nyelvtechnológiai eszközökkel, ezen belül részben az ún. gépi tanulás segítségével végzik. E tevékenység célja - a számítógépes nyelvleíráson túl - különféle nyelvtechnológiai alkalmazások támogatása: ilyen például a helyesírás-ellenőrzés, a keresőprogramok, a szótárprogramok és a gépi fordítás (lásd erről PRószéKY, 2005). A pszichológiai tartalomelemzést is nyelvtechnológiai alkalmazásnak tekinthetjük.

A korábbi magyar nyelvủ vizsgálatokhoz hasonlóan, izolált kiscsoportokon végzett többnyelvű elemzéseinkhez is a NooJ korpusznyelvészeti fejlesztő környezetet használtuk. A NooJ jelenleg 22 nyelven tartalmaz ún. nyelvi forrásokat (linguistic resources), melyek pszichológiai tartalomelemzés alapjául szolgálhatnak.

Az utóbbi években nemzetközi együttműködések keretében két földi űranalóg környezetben végeztünk-végzünk empirikus vizsgálatokat: a moszkvai Mars-500 szimulációban és az antarktiszi Concordia Kutatóállomáson keletkezett szövegeket elemezzük.

\section{A Mars-500 üranalóg szimuláció}

A széles körű nemzetközi együttmúködés keretében, jelentős részben az Európai Ürügynökség (European Space Agency, ESA) részvételével megvalósított Mars500 szimuláció az Orosz Tudományos Akadémia keretében működő moszkvai Orvosbiológiai Intézet (Institute for Biomedical Problems, IBMP) telephelyén zajlott, 2010 júniusa és 2011 novembere között. A kísérletben hattagú nemzetközi legénység (három orosz, két európai és egy kínai férfi) összesen 520 napot töltött egy 
olyan létesítményben, melyben a Marsra utazást, a leszállást, majd a hazautat modellezték. ${ }^{7}$ Az MTA TTK KPI kutatócsoportja az orosz partnerintézménnyel közösen a legénység és a földi irányítás között zajló kommunikáció elemzésében vett részt. A legénység videó üzeneteit (több mint 2000 fájl, csaknem egymillió karakter, mintegy 150000 szó) elektronikus úton megkaptuk, és többféle tartalomelemzési kérdésfeltevés jegyében elemeztük (Gushin, Shved, Vinokhodova, Vasylieva, Nitchiporuk, Ehmann és Balázs, 2012; Ehmann, Balázs, ShVed, BÉnet és Gushin, 2013; Gushin, Shved, Ehmann és BaLázs, 2015).

\section{Az antarktiszi Concordia Kutatóállomás}

Az Európánál csaknem másfélszer nagyobb területủ Antarktiszon több mint harminc nemzet csaknem hetven kutatóállomást múködtet. Ezek egyike az ESA által olasz és francia együttműködésben létesített, a tengerparttól több mint ezer kilométerre, 3233 méter tengerszint feletti magasságban épült Concordia Kutatóállomás. ${ }^{8}$ A föld legtávolabbi pontján lévő állomás áttelelő személyzetének orvosi és pszichológiai kutatása az ESA egyik legjelentősebb üranalóg-kutatási tevékenysége. Az ESA COALA és a CAPA projektjeinek keretében nemzetközi együttműködésben 2013 óta a kilencedik, a tízedik és a tizenegyedik áttelelő legénységet vizsgáljuk. A vizsgálat első évében, 2013-ban összesen 15 résztvevő (9 francia, 5 olasz és 1 görög) közül tizennégy személytől kaptunk heti rendszerességű videónaplókat; a 2014-es naplók leíratása folyamatban van, a 2015-ös naplók pedig jelenleg készülnek. Ezért erről a kutatásról csak előzetes eredményekről tudunk beszámolni. Az első évben a 36 héten át felvett, angol, olasz és francia nyelvű, elektronikusan leíratott videónaplók mintegy másfél millió karakterből, háromszázezer szóból állnak.

\section{Az üranalógokban végzett tartalomelemzés néhány témaköre és kérdésfeltevése}

Az orosz űrpszichológusok hagyományosan nagy hangsúlyt fektetnek arra, hogy a hosszú távú ủrutazások során a legénységi autonómia optimális tartományban maradjon. Ezért orosz kérésre a Mars-500 legénységi kommunikáció egyik elemzése során azt vizsgáltuk, hogy a földi irányítással folytatott kommunikációban a szükségleteket kifejező szavak spontán használatának gyakorisága mennyiben tükrözi a növekvő legénységi autonómia tényét. Azt találtuk, hogy e gyakoriság a küldetésben eltöltött idő függvényében szignifikánsan csökkent (GUSHIN és mtsai, 2015).

A 2013-as Concordia videónaplók elemzésekor a harmadik negyedbeli érzelmi diszfória kialakulását, az ismert Q3 jelenséget vizsgálatuk - amint ezt korábban már a HungaroMars elemzésben is tettük. A pozitív és negatív érzelemszavak talá-

\footnotetext{
7 http://mars500.imbp.ru/;

http://www.esa.int/Our_Activities/Human_Spaceflight/Mars500/ESA_and_isolation_studies.

8 http://www.esa.int/Our_Activities/Human_Spaceflight/Concordia
} 
lati arányából számolt Emocionalitás mutató révén megállapítottuk, hogy a személyzet érzelmi állapota az áttelelés első negyedéhez viszonyítva a harmadik negyedben szignifikánsan rosszabbodott, majd a negyedik negyedben ez utóbbihoz képest szignifikánsan javult.

Végezetül egy tágabb területről, az elszigeteltségben jelentkező szubjektív időélmény változásról, az időtudatosság tartalomelemzés révén történő mérhetőségéről szeretnénk szólni. Korábbi munkáinkban áttekintettük az idóélménnyel kapcsolatos pszichológiai elméleteket, tartalomelemzési lehetőségeket, és magyar nyelvű mintán empirikus vizsgálatokat is végeztünk (EHMANN, 2004a, b, c; EHMANN, KIS, NASZÓDI és LÁSZLÓ, 2005). Ennek során magyar nyelvű szövegek elemzésére alkalmas időszótárakat készítettünk, egyebek között az alábbi kategóriákra: Gyorsaság-Lassúság; Kezdet-Befejezés; Pillanatnyiság-Huzamosság; és Ismétlődés (EHManN, GARAMI, NASZÓDI, Kis és László, 2007; EHMANN és GARAMI, 2010).

Izolált kiscsoportokkal végzett kutatásainkban ezek a vonatkozások újra előkerültek. Mind a Mars-500 legénysége, mind a 2013-as Concordia-áttelelók esetében azt találtuk, hogy az időre utaló szavak spontán említési gyakorisága (mint az idői tudatosság markere) az ingerszegény időszakokban szignifikánsan csökkent. A Mars-500-ban az ingerszegényebb hónapokat megszakította a szimulált Marsra szállás, amikor is az időszavak említése meredeken megemelkedett; a Concordiaáttelelők esetében a téli sötétség heteiben volt a legalacsonyabb az időre vonatkozó említések száma.

Jelenleg a finomabb felbontású idői kategóriák elemzéséhez szükséges keresőalgoritmusokon dolgozunk, és több más kategóriát is vizsgálunk, egyebek közt a munkával és a teljesítménnyel kapcsolatos említések alakulását.

\section{ÖSSZEFOGLALÁS}

Tanulmányunkban áttekintettük a pszichológiai tartalomelemzés fő megközelítésmódjait és izolált kiscsoportok pszichodinamikai vizsgálatában történő alkalmazásait. Az elmondottakhoz három zárógondolatot szeretnénk illeszteni.

Az első, hogy a nyelvtechnológia jelenlegi állása mellett lehetőségünk nyílik arra, hogy korábbi jeles szerzők elgondolásait a jelenleg elérhető tartalomelemzési eszköztár segítségével újra szemügyre vegyük és továbbfejlesszük.

A második, hogy az egyre korszerűbb nyelvtechnológiai eszközök elérhetősége nem írja felül az elmúlt fél évszázad során összegyűlt tartalomelemzési és pszichometriai tudást, sőt, éppen ellenkezőleg - a pszichológiai kutatás szinte minden területén lehetőséget ad a megközelítések ötvözésére.

Végül, tanulmányunkkal fel szeretnénk hívni a hazai pszichológus olvasóközönség figyelmét arra, hogy az informatika és a nyelvtechnológia gyors ütemü fejlődése a közeljövőben jelenleg még beláthatatlan módon átrajzolhatja a pszichológiai tartalomelemzés tablóját. 


\section{IRODALOM}

Antonovsky, A. (1979). Health, Stress and Coping. San Francisco: Jossey-Bass.

Antonovsky, A. (1987). Unraveling The Mystery of Health - How People Manage Stress and Stay Well. San Francisco: Jossey-Bass.

Balázs L., Barkaszi I., Czigler I. és TAKÁCS E. (2015). Agyműködés súlytalanságban: Kísérlet a Nemzetközi Ürállomáson. Magyar Tudomány, 9, 1045-1052.

BARANYI, P., \& CSAPÓ, A. (2012). Definition and Synergies of Cognitive Infocommunications. Acta Polytechnica Hungarica, 9, 67-83.

BeChtel, R. B., \& Berning, A. (1991). The third-quarter phenomenon: Do people experience discomfort after stress has passed? In A. A. Harrison, Y. A. Clearwater, \& C. P. MCKAY (Eds.), From Antarctica to outer space: Life in isolation and confinement (261-266). New York: Springer Verlag.

Berelson, B. (1952/1971). Content Analysis in Communication Research. New York: Hafner Publishing Company.

BYrd, R. E. (1938). Alone. New York: Putnam.

Ehmann B. (2002). A szöveg mélyén. Pszichológiai tartalomelemzés. Budapest: Új Mandátum.

EHMAnN B. (2004a). Tartalomelemzési módszerek a szubjektív időélmény vizsgálatára laikus beszélők szövegeiben. In ERŐS F. (szerk.), Az elbeszélés az élmények kulturális és klinikai elemzésében (57-73). Pszichológiai Szemle Könyvtár 8. Budapest: Akadémiai Kiadó.

EHmann B. (2004b). Tartalomelemzési módszerek a szubjektív időélmény vizsgálatára laikus beszélők szövegeiben. Magyar Pszichológiai Szemle, 59(3), 345-362.

EHMANN B. (2004c). A szubjektív időélmény mintázatainak pszichoanalitikus és narratív pszichológiai párhuzamai. Pszichológia, 24(4), 403-425.

Ehmann B., CSERTő I., FülöP É., KŐVÁGÓ P., PÓlya T. és LÁSZló J. (2014). Narratíu kategoriális tartalomelemzés: A NARRCAT. In TANÁcs A., VARGA V. és Vincze V. (szerk.), X. Magyar Számítógépes Nyelvészeti Konferencia: MSZNY 2014. (136-147.) Szeged: Szegedi Tudományegyetem Informatikai Tanszékcsoport.

EhMANN B., Kiss B., NASzÓdi M. és LÁSZLÓ J. (2005). A szubjektív időélmény tartalomelemzéses vizsgálata. A LAS Vertikum időmodulja. Pszichológia, 25(2), 133-142.

Ehmann, B., \& Garami, V. (2010). Narrative Psychological Content Analysis with NooJ: Linguistic Markers of Time Experience in Self-Reports. In T. VÁRADI, J. KuTI, M. SilberzTein (Eds.), Applications of Finite-State Language Processing - Selected Papers from the 2008 International NooJ Conference (186-196). Newcastle, UK: Cambridge Scholars Publishing.

Ehmann, B., Balázs, L., Fülöp, É., Hargitai, R., Kabai, P., Péley, B., et al. (2011). Narrative Psychological Content Analysis as a Tool for Psychological Status Monitoring of Crews in Isolated, Confined and Extreme Settings. Acta Astronautica, 68(9-10), 15601566.

Ehmann, B., Balázs, L., Shved, D., BÉnet, V., \& Gushin, V. (2013). The Russian Linguistic Resources in Space Psychological Research. In A. DonabÉdian, V. Khurshudian, \& M. SilberzTein (Eds.), Formalising Natural Languages with NooJ: Selected Papers from the NooJ 2012 International Conference (Paris, France) (150-161). Newcastle, UK: Cambridge Scholars Publishing. 
Ehmann, B., Garami, V., Naszód, M., Kis, B., \& László, J. (2007). Subjective Time Experience: Identifying Psychological Correlates by Narrative Psychological Content Analysis, Empirical Text and Cultural Research 3, 14-25.

FÜlÖP, É., Csertő, I., Ilg, B., SZABÓ, Zs. P., Slugoski, B., \& LÁsZló, J. (2014). Emotional elaboration of collective traumas in historical narratives. In J. P. Forgas, O. VInCZE, \& J. LÁszló (Eds.), Social Cognition and Communication (245-262). New York: Psychology Press.

Galarza, L., \& Holland, A. W. (1999). Selecting astronauts for long-duration space missions. Proceedings of the International Conference on Environmental Systems, Denver, CO, July 12-15, 1999.

Gushin, V. I. (2003). Problems of Distant Communication of Isolated Small Groups. Human Physiology, 29(5), 548-555.

Gushin, V. I., Efimov, V. A., Smirnova, T. M., Vinokhodova, A. G., \& Kanas, N. (1998). Subject's perceptions of the crew interaction dynamics under prolonged isolation. Aviation, Space, and Environmental Medicine, 69, 556-561.

Gushin, V., Shved, D., Vinokhodova, A., Vasylieva, G., Nitchiporuk, I., Ehmann, B., \& BALAzS, L. (2012). Some psychophysiological and behavioral aspects of adaptation to simulated autonomous Mission to Mars. Acta Astronautica, January-February 2012, 52-57.

Gushin, V., Shved, V., Ehmann, B., \& Balazs, L. (2015). Crew-MC Interaction During Communication Delay In Mars-500. Paper submitted to Acta Astronautica.

Helmreich, R. L. (2000). Culture and error in space: implications from analog environments. Aviation, Space, and Environmental Medicine. 71(9, Suppl.), A133-A139.

Holsti, O. R. (1969), Content Analysis for the Social Sciences and Humanities. Reading, MA: Addison-Wesley Publishing Company.

Ihle, E. C., Ritsher, J. B., \& KanAs, N. (2006). Positive psychological outcomes of spaceflight: An empirical study. Aviation, Space, and Environmental Medicine, 77, 93-101.

KANAS, N. (1985). Psychological factors affecting simulated and actual space missions. Aviation, Space, and Environmental Medicine, 56, 806-811.

KANAS, N. (1987). Psychological and interpersonal issues in space. American Journal of Psychiatry, 144, 703-709.

Kanas, N., \& Manzey, D. (2008). Space Psychology and Psychiatry. Dordrecht, The Netherlands: Kluwer Academic Press.

Kanas, N., Salnitskiy, V., Gushin, V., Weiss, D. S., Grund, E. M., Flynn, C., et al. (2001). Asthenia: does it exist in Space? Psychosomatic Medicine, 63, 874-880.

Kanas, N., Salnitskiy, V., Weiss, D. S., Grund, E. M., Gushin, V., Kozerenko, O., et al. (2001). Crewmember and ground personnel interactions over time during Shuttle/Mir space missions. Aviation, Space, and Environmental Medicine. 72, 453-461.

Kelly, A. D., \& Kanas, N. (1992). Crewmember communication in space: A survey of astronauts and cosmonauts. Aviation, Space, and Environmental Medicine, 63, 721-726.

KRIPPENDORFF K. (1980/1995). A tartalomelemzés módszertanának alapjai. Budapest: Balassi Kiadó.

KrippendorfF, K. (2004). Content Analysis. An Introduction to Its Methodology. Thousand Oaks: Sage Publications.

LÁszló J. (2005). A történetek tudománya. Bevezetés a narratív pszichológiába. Budapest: Új Mandátum. 
LÁszLÓ J. (2012). Történelemtörténetek. Bevezetés a narratív szociálpszichológiába. Budapest: Akadémiai Kiadó.

LÁszLó, J. (2008). The science of stories: An introduction to narrative psychology. London-New York: Routledge.

LÁszló, J. (2013). Historical Tales and National Identity. An introduction to narrative social psychology. London-New York: Routledge.

LÁszló, J., \& Ehmann, B. (2014). Narrative Social Psychology. In J. P. Forgas, O. Vincze, J. LÁszló (Eds.), Social Cognition and Communication (205-228). New York: Psychology Press.

László, J., Csertő, I., Fülöp, É., Ferenczhalmi, R., Hargitai, R., Lendvai, P., et al. (2013). Narrative language as expression of individual and group identity: The Narrative Categorical Content Analysis (NarrCat). Sage Open.

http://sgo.sagepub.com/content/spsgo/3/2/2158244013492084.full.pdf. megnyitva 2015. 08. 17.

LÁszló, J., Ehmann, B., PÉley, B., \& Pólya, T. (2002). Narrative psychology and narrative psychological content analysis. In J. LÁszLó, \& S. R. WENDY (Eds.), Narrative Approaches in Social Psychology (9-25). Budapest: New Mandate.

Leon, G. R., Sandal, G. M., Fink, B. A., \& Ciofani, P. (2011). Positive Experiences and Personal Growth in a Two-Man North Pole Expedition Team. Environment and Behavior, 43(5), 710-731.

Mocellin, J., \& Suedfeld, P. (1991). Voices from the ice: Diaries of polar explorers. Environment and Behavior, 23(6), 704-722.

Neuendorf, K. (2002). The Content Analysis Guidebook. Thousand Oaks, London-New Delhi: Sage Publications.

Oravecz, Cs., VÁradi, T., \& Sass, B. (2014). The Hungarian Gigaword Corpus. LrecConf.Org, 1719-1723.

http://www.lrec-conf.org/proceedings/lrec2014/pdf/681_Paper.pdf. megnyitva 2015. 08.17.

OsGoOD, C. E., \& WALKer, E. G. (1959). Motivation and language behavior: Content analysis of suicide notes. Journal of Abnormal and Social Psychology, 59, 58-67.

PAlinkas, L. A. (1986). Health and performance of Antarctic winter-over personnel: a follow-up study. Aviation, Space, and Environmental Medicine. 57, 954-959.

Palinkas, L. A., \& Suedfeld, P. (2008). Psychological effects of polar expeditions. The Lancet, 371, 153-163.

Pennebaker, J. W. (2011). The Secret Life of Pronouns - What our Words Say about Us. New York: Bloomsbury Press.

PrószéKy G. (2005). A nyelvtechnológia és alkalmazásai. Budapest: eVilág Kiskönyvtár sorozat, 2. kötet.

ROHRER, J. H. (1961). Interpersonal relationships in isolated small groups. In B. E. Flaherty (Ed.), Symposium on Psychophysiological Aspects of Space Flight (263-271). New York: Columbia University Press.

SANDAL, G. M. (2000). Coping in Antarctica: is it possible to generalize results across settings? Aviation, Space and Environmental Medicine, 7(9, Suppl), A37-A43.

SAndal, G. M., VAernes, R., Bergan, T., WArmcke, M., \& Ursin, H. (1996). Psychological reactions during polar expeditions and isolation in hyperbaric chambers. Aviation, Space, and Environmental Medicine, 67, 227-234. 
Santy, P. A. (1994). Choosing the Right Stuff: The Psychological Selection of Astronauts and Cosmonauts. London: Praeger.

SCHWARTZ, S. H. (1992). Universals in the content and structure of values: theoretical advances and empirical tests in 20 countries. Advance in Experimental Social Psychology, 25, $1-65$.

SELLS, S. B. (1966). A model for the social system for the multiman extended duration space ship. Aerospace Medicine, 37, 1130-1135.

Strange, R. E., \& Youngman, S. A. (1971). Emotional aspects of wintering over. Antarctic Journal of the United States, 6, 324-347.

STuster, J. (2010). Behavioral Issues Associated with Long-Duration Space Expeditions: Review and Analysis of Astronaut Journals. Experiment 01-E104 (journals): Final Report. NASA, Johnson Space Center, Houston, TX 77058.

http://ston.jsc.nasa.gov/collections/TRS.

megnyitva 2015. 08.17.

Stuster, J., Bachelard, C., \& Suedfeld, P. (1999). In the Wake of the Astrolabe: Review and Analysis of Diaries Maintained by the Leaders and Physicians at French Remote Duty Stations. Technical Report to the National Aeronautics and Space Administration (February). http://www.anacapasciences.com/publications/Astrolabe.pdf. megnyitva 2015. 08.17.

Stuster, J., Bachelard, C., \& Suedfeld, P. (2000). The Relative Importance of Behavioral Issues During Long-Duration I.C.E. Missions. Aviation, Space, and Environmental Medicine, 71(9), 17-25.

SuEDFELD, P. (2005). Invulnerability, coping, salutogenesis, integration: four phases of space psychology. Aviation, Space, and Environmental Medicine. 76(6, Suppl.), B61-B66.

SuEdFELd, P. (2006). Space memoirs: Value hierarchies before and after missions - A pilot study. Acta Astronautica, 58, 583-586.

Suedfeld, P., \& Steel, G. D. (2000). The environmental psychology of capsule habitats. Annual Review of Psychology, 51, 227-253.

Suedfeld, P., \& Weiszbeck, T. (2004). The impact of outer space on inner space. Aviation, Space, and Environmental Medicine, 75(7, Suppl.), C6-C9.

Suedfeld, P., Brcic, J., \& Legkaia, K. (2009). Coping with the problems of space flight: Reports from astronauts and cosmonauts. Acta Astronautica, 65, 312-324.

Suedfeld, P., Brcic, J., Johnson, P. J., \& Gushin, V. (2012). Personal growth following long-duration spaceflight. Acta Astronautica, 79, 118-123.

SzIrMai M. (2005). Bevezetés a korpusznyelvészetbe. Budapest: Tinta Könyvkiadó.

Tedeschi, C., \& Calhoun, L. G. (1996). The Posttraumatic Growth Inventory: measuring the positive legacy of trauma. Journal of Trauma and Stress, 9(3), 455-471.

Vincze, O., Ilg, B., \& Pólya, T. (2014). The role of narrative perspective in the elaboration of individual and historical traumas. In J. P. Forgas, O. Vincze, \& J. LÁszLó (Eds.), Social Cognition and Communication (229-244). New York: Psychology Press.

WeIntraub, W. (1989). Verbal Behavior in Everyday Life. New York: Springer.

Wolfe, T. (1979). The Right Stuff. New York: Farrar, Straus, Giroux. 


\title{
FROM THE ANTARCTICA TO THE OUTER SPACE: \\ THE USE OF PSYCHOLOGICAL CONTENT ANALYSIS FOR THE STUDY OF ISOLATED SMALL GROUPS
}

\author{
EHMANN, BEA - BALÁZS, LÁSZLÓ
}

The paper is based on a commemorative lecture dedicated to Ferenc Mérei (1909-1986), the prominent Hungarian social psychologist (presented on the 24th Scientific Assembly of the Hungarian Psychological Association, Eger, Hungary, May 28-30, 2015). It reviews the psychological research of isolated small groups, with special focus on psychological content analysis of terrestial space analog environments and space missions. In this scope, four main types of psychological content analysis - thematic, psychological construct based, narrative and multilingual corpus linguistic approaches -, including their conceptual and language technological backgrounds, are discussed. The authors also present some of their own results obtained in Hungarian and international cooperation. A broader aim of the paper is to shed light upon the opportunities and challenges of the comprehensive applicability of content analysis in psychological research.

Key words: isolated small groups, space psychology, psychological content analysis, narrative psychological content analysis, corpus linguistic content analysis, NooJ 